\title{
Basic epistemology of biographical research: a review based on the extraordinary life history of a young offender
}

\author{
Epistemología básica de la investigación biográfica: Revisión a través de la \\ extraordinaria historia de vida de un menor infractor
}

\author{
David Herrera-Pastor \\ dherrera@ugr.es \\ Facultad de Ciencias de la Educación y del Deporte de \\ Melilla. Universidad de Granada, España
}

\author{
Nick Frost \\ N.Frost@leedsbeckett.ac.uk \\ School of Health and Community. Leeds Beckett \\ University, Reino Unido
}

Received: 30 Enero 2021

Accepted: 20 Mayo 2021

Publicación: 01 Junio 2021

Cita sugerida: Herrera-Pastor, D. y Frost, N. (2021). Basic epistemology of biographical research: a review based on the extraordinary life history of a young offender. Revista Latinoamericana de Metodología de las Ciencias Sociales, 11(1), e086. https://doi.org/10.24215/18537863e086

\begin{abstract}
This article analyses the basic epistemology of biographical research methodology. This analysis is grounded on the life history of a Moroccan boy who entered Spain illegally, but after being processed by the juvenile justice system, became a social educator. Some methodological aspects of this case are examined, including biographical hermeneutics; the oftenconfused concepts of 'life story' and 'life history'; the main characteristics of the method, including the usually neglected vision of the 'other'; life as a process; and the idea of subject. The educational, ethical, and political dimensions analysed make visible counter-narratives that question the status quo and pursue social justice.
\end{abstract}

Keywords: Social sciences, Biographical research methodology, Epistemology, Minorities, Social justice.

Resumen: Este artículo analiza la epistemología básica de la metodología de investigación biográfica. Dicho análisis se sustenta empíricamente en la historia de vida de un joven marroquí que llegó a España de manera ilegal y tras un proceso de justicia juvenil se convirtió en educador social. Se examinan algunos aspectos metodológicos de este caso, incluyendo la hermenéutica biográfica; los conceptos 'relato de vida' e 'historia de vida', habitualmente confundidos; las principales características del método, incluyendo la visión del 'otro'; la vida como proceso; y la idea de sujeto. Las dimensiones educativa, ética y política analizadas hacen visibles contranarrativas que cuestionan el estatus quo y persiguen la justicia social.

Palabras clave: Ciencias Sociales, Metodología de investigación biográfica, Epistemología, Minorías, Justicia Social.

\section{INTRODUCTION}

The ideas presented in this paper are based on a research project carried out in the south of Spain that was funded by the Department of Innovation, Science and Business Development of the Andalusia 
region (Consejería de Innovación, Ciencia y Empresa de Andalucia). It concerns the case of Abdulla (a pseudonym), a young adolescent who became involved in offending, and later went on to become a 'social educator/pedagogue' after completing a rehabilitation process. he research was focused on analysing the key factors involved in his rehabilitation process, which made such a substantial change possible. It is worth noting that significant results such as these are not commonly found in the juvenile justice system in Spain. he aim was to analyse the different factors which had an influence on that transformation process.

The biographical research methodology was used to carry out the study. Although a vast amount of data was collected, the main sources were: interviews with Abdulla and with 12 other significant individuals (a Judge, the Deputy director of the Detention Centre (DC), Abdulla's tutor at the DC; his foster mother, his tutor on probation, one of his biological brothers and some of his friends), several relevant documentary sources and more than 200 hundred photographs, mostly from his time in detention.

The object of study of this article is the methodology used. Some contributions on biographical research methodology will be made based on both the research process and on the narrative that was produced throughout this process. The aim is to contribute to a discussion about this methodology in the social sciences and further existing knowledge and practice in relation to its contemporary epistemology. In particular, this manuscript is focused on the most important methodological dilemmas and vicissitudes that had to be faced during the research process. Specifically, the epistemological aspects that will be addressed are: A) The logic of the biographical approach which concerns how best to adapt and reconstruct human experience. B) The significant differences between 'Life Story' and 'Life History', based on both origin and purpose. C) The characteristics that make the biographical method a genuinely suitable method for the study of certain cases, in particular for excluded minorities; essentially, in providing an understanding the Other's view of social reality (their truth). In exploring the life processes that underpin how decisions are made, a biography must also reveal the individual specifics and at the same time, the context in which the person is immersed. In this sense, narratives are an ethnographic lens not only to understand a person's life, but the universe in which that person operates, and the elements that influence their development. D) Furthermore, in line with the philosophy of critical theories, biographical research has an educational, ethical, and political genuine added value in relation to social justice. In the contemporary world of hegemonic discourses, counter-narratives serve to challenge simplistic stereotypes and potentially enable the empowerment of marginalised voices. In this sense, critical social research aims to contribute to the improvement of society as a whole.

\section{THE SHIFT FROM BEING A MINOR OFFENDER TO BECOMING A SOCIAL EDUCATOR/ PeDAgogue. Understanding AbDulla's case}

In order to better contextualise and understand the arguments in relation to the biographical research methodology used, a summary of Abdulla's biography will be presented. This summary draws on all the information collected during the fieldwork, which is explained in the following section (3. Methods):

Abdulla was born into a very large family in northern Morocco (he was the youngest of 10 children). He lived in a very poor,
semi-rural environment, with no running water in the family home. The road to his village was un-tarmacked. Opportunities
for social mobility were limited to the reproduction of the same life patterns of his parents and older brothers (his father
was a labourer and most of his male siblings were transport workers), that is, unskilled jobs, long working hours and low
remuneration. At the age of 13 he dropped out of school and started working in a coffee shop where he had to spend around
12 hours every shift to earn one euro a day. After several years of various precarious jobs in clothing bazaars), he began to
realise that there were people who enjoyed very different living conditions. He was a very capable individual who had higher
expectations of life, but he felt that he had no chance of fulfilling them there. In addition, he had external influences (mostly
from Europe) which showed that another way of life seemed to be solid and real. One day, he embarked on a boat loaded
with hashish and crossed the Strait of Gibraltar, an 'operation/job' that earned him 6000 euros.
Since that day, he began to work for that organisation along the coast of southern Spain, organising the landings of
those boats and distributing the 'merchandise'. About one year later the police arrested him. As he was 17 years old, he 
was sentenced to a two-year rehabilitation process that was divided into two phases: the first one, more extended, in a detention centre, and the second one, on probation. Abdulla was a young immigrant who had become involved in a mafia as a means to pursue a better life. He adapted very well to the rehabilitation process and tried to take advantage of it in order to achieve his migration objective. As a result of the excellent track record he had had during that process, he was ultimately offered the opportunity to start working as an auxiliary member of staff responsible for protecting minors, mostly from Arab backgrounds. Some years later, he was promoted and began to work as a social educator/pedagogue. He continues to work there to this day, more than fifteen years later. That work allowed him to achieve his purpose of a better life, a new life as he had envisioned in Morocco some years before.

\section{Methods}

In order to locate key factors and understand the meaning of Abdulla's experience in context, finding out the elements which contributed to the positive evolution of his life, it was necessary to consider what happened before, during and after the change process. The biographical method seemed to be the most suited to this particular research project.

As can be seen in the following Table 1, a diverse range of information sources and multiple methods of gathering data was used to produce a rigorous, exhaustive and rich biographical account: 
TABLE 1

Summary of information sources and data gathering techniques.

Biographical Interviews:

5 with the research subject.

- 12 with other relevant informants, which played different roles in the biography.

The following in italics participants had a dual relationship with Abdulla and were interviewed accordingly:

Abdulla's brother.

The judge in the case.

The deputy director of the Detention Centre (DC).

- A social worker at the $D C$, and later Abdulla's current line manager in the NGO where he works today.

Abdulla's tutor at the DC.

An educator at the DC.

Two monitors at the $D C$ and now friends of Abdulla.

A domestic service worker at the $D C$, and later Abdulla's foster mother.

Abdulla's tutor during his probation period.

An educator during the probation period.

A work colleague, flatmate and friend of Abdulla.

Other data sources:

- SWOT analysis (strengths, weaknesses, opportunities, and threats) for each informant.

- Abdulla's iconographic records (over 200 photographs) + complementary interviews,

- A manuscript by Abdulla ('Meaning of work') + complementary interview.

- Official documents: File at the Minors' Court + File at the Youth Rehabilitation Board.

- Current legislation: Act 5/2000, of 12 January, Regulating the Criminal Responsibility of Minors.

- Researchers' field notebook.

- Detention Centre Tutor Report (14 May 2001).

- Member's check (with Abdulla and the other key informants).

- A bio-gram and socio-gram + complementary interview.

Organising and processing this large quantity of raw data required an enormous amount of work of categorisation and analysis. All information was categorised using the qualitative data analysis software NVivo. The main categories created were: 1) Original socio-cultural system. 2) Juvenile justice system. 2.1) 
Detention centre period. 2.2) Probation. 3) Socio-cultural system after the rehabilitation process. Each of these had several sub-categories. And all of them were traversed by the following cross-cutting categories: I) Delinquency. II) Immigration. III) Identity.

All the data outlined in the table were used for constant comparison (Glaser, 1965), to clarify some parts of the account and to enrich it with multiple points of view. Eventually, Abdulla's biography was written following the cross-narrative model (Lewis, 1965), where the voices of the informants, the photographs and the information contained in the different documents weaved a narrative that completed the case studied in a plural and holistic way. This technique allowed the various testimonies to be confronted and different analyses were drawn.

\subsection{Research ethics}

In the informed consent process undertaken with every informant or body, the anonymity of the informant, the social actors, and of all the relevant institutions and bodies appearing in the account were guaranteed. Pseudonyms were used in order to preserve identity. The confidentiality and safe keeping of all the information gathered was guaranteed too, in line with the University's regulations.

Consistently with the ethical approval (Herron, 2019) and with the principles of narrative enquiry (Oakley, 2010), the information was returned to the informants at two clearly differentiated points in the study: before and after analysis. The participant check with Abdulla was not carried out in a traditional manner (providing him with the texts to read alone and then make any pertinent comments). Abdulla had some difficulties with reading and writing, and was uncomfortable with both. It should be remembered that Spanish was his second language and that reading such a long document was challenging. As a result, one of the researchers read the transcription of each of the biographical interviews to him. The other informants were also provided with a preliminary member check of the information. This member check was carried out by sending each of them the verbatim transcription of the interview.

The report with the analysis was sent to all informants for member checking once it had been completed. A letter enclosed with the report gave the informants a deadline to read the document and make any comments they wished. It was considered that 45 days was sufficient time to review the document. Only Dani(Abdulla's friend, work colleague and flatmate) made some observations, specifically, he wished to clarify Abdulla's role when he started working. This observation was taken into account and the corresponding amendments were made to the research work. Abdulla was given the report in person. He informed us that he did not need to see any documents, as he was sure everything was fine. The authors insisted on meeting with him to give him the report, and said they were particularly interested in his feedback, and it would also make the member check process more rigorous. They met and gave him the report over coffee: it took around two hours to give him an overview of the full study.

\section{Results AND Discussion}

The methodological contributions that have been made on biographical research on the basis of the study are presented below. These contributions draw on the most important methodological reflections that were addressed during the research process. They are based on the biography that was extracted, and on the procedures carried out. 


\title{
4.1. Biographical hermeneutics
}

\begin{abstract}
Allport said 'Let us imagine the case of 12-year-old John, who has a family background of poverty, in which his father was a delinquent, his mother rejected him and he lives in an extremely deprived part of the town. Let us suppose that $70 \%$ of youngsters with the same background become delinquents. Does this mean that there is a $70 \%$ chance that John will become a delinquent? Not at all. John is a unique being with his own unique genetic heritage; his life experience is his and his only. His world contains unique influences, which are unknown to the statistician: perhaps an affectionate relationship with one of his teachers, or judicious words from a neighbour. Such factors can be decisive and can render these percentage probabilities worthless. This $70 \%$ of probability does not exist for John. He may become a delinquent, or he may not' (Pujadas-Muñoz, 2002, p. 41).
\end{abstract}

Human existence cannot be reduced to a closed series of nomothetic rules. The principles and foundations of biographical research are based on a hermeneutic approach, much in keeping with the post-modern turn and its philosophical pragmatism roots (Rorty, 1998) and as prominently articulated by Berger and Luckman (1991), in terms of social construction. General assumptions about the relationship between specific human beings and their social context cannot be made 'objectively' and absolutely. This does not mean that there are no specific social rules and cultural codes which mediate the development of human action. What it means is that social reality is not always comfortable with rigid systematisation and the imposition of univocal rules to explain an event - on the contrary, there is an irreducible subjective factor, one which is fortuitous and unpredictable, which must be taken into account (Michael et al, 2018).

Narrative is the method which best coincides with the experience of a person, and is the most suitable way to recreate it. Qualitative research and narrative logic go hand-in-hand within social science. Narrative research, as a branch of interpretive approach, shares some of the general methodological principles of qualitative research. In a broader sense it can be understood that, at heart, all qualitative research is in some way a form of narrative research (Denzin, 2012).

The narrative embraces the complexity of human life and its multiple, interacting variables, rather than reducing experience to a limited set of variables. It casts light on the meanings that each individual gives to the acts that they are involved in, and how and why those meanings are arrived at (Feldman-Barrett, 2018). At the same time, it illustrates the context in which events take place, which should help to develop plausible interpretations and better understand the issue being studied. This is essential where we emphasise how social elements are related contingently (Bertaux, 2005): each acts upon and 'feels the force of another through stimulus-feedback, rather than causally, as this is a relational epistemology (Linares, 2018). Specifically, the biographical method, as used in this case, deals with the essential reciprocity of actions established between the social components that make up the situation under study.

As Stanley (2012) argued, biographical analysis does not deal exclusively with individual particularities, but as an ethnographic method it aims, apart from analysing the lived situation under study, to analyse their component elements or interactions and the social system in which they interact. In this sense, biographical narratives are prisms that make the intersection between the individual and the structural visible. Rather than providing an explanation as such, the biographical methodology strives to understand the workings that give rise to social phenomena based on interpreting life. This is not a passive form of understanding; rather, it is, in pragmatic terms, that form of understanding which improves action and makes the exchange of ideas underlying practice more efficient. Georg Henrick von Wright illustratively distinguishes between researching to offer explanations and researching to further understanding:

'It could be said that practically any explanation, whether causal, teleological or any other type, increases our understanding of things. But 'understanding' also has a psychological aspect which is lacking in the 'explanation' (...). Understanding, as a characteristic method of humanities, is a form of empathy or recreation in the mind of the thinker of the mental climate, thoughts, feelings and motivations of the object of study... Understanding is also linked to intentionality in a way that explanation is not' (in Stake, 2010, p. 42-43). 


\subsection{Difference between Life Story and Life History}

'Life Story' and 'Life History' terms are frequently used indiscriminately within the narrativebiographical approach. According to Smith (2012), life story is a retrospective narration by the protagonist of his or her life and of specific fragments/aspects of it. For Pujadas (2002, p. 13) the life story was introduced 'to refer exclusively to the biographical narration of a subject which, occasionally, can be published untouched, in order to provide greater testimonial force, conserving even the linguistic peculiarities of the person'. A shared idea can be distilled from these definitions: Life story is the narration that a subject makes of an experience. This is how Bertaux understood it, when making a broader and more open definition than his colleagues: 'there is a life story from the moment there is a description in narrative form of a fragment of the experience lived' (Bertaux, 2005, p. 12). In accordance with this definition, life story can also be considered to refer to any biographical expression (from personal experience) which narrates the life of a subject.

In contrast, Pineau and Le Grand (1996) held that 'life history' (in French historie de vie) refers to the case study of a specific person, including not only his or her life story but any other further information or documentation which allows the reconstruction of this biography in the most exhaustive and objective manner possible. Bolívar, Domingo and Fernández (2001, p. 28-29) agreed with this idea: 'elaboration (by biographers or researchers) as the case study of the life of a person or institution, representing different forms of elaboration and analysis'. Normally, in addition to the life story, multiple biographical materials (such as documents related to the biography in question and photographs) are used to give the biographical study greater rigour and exhaustiveness.

In this regard, Roberts (2002, p. 3 ) understands that 'the term life story applies commonly to the narration made by the author, whilst life history is the work presented by researchers, setting out the interpretive inferences made a posteriori'. Goodson (2012) essentially agreed and stated that a life story is the initial account a person makes of his or her life; whereas life history is a triangulated account in which the tip of the tripod is the life story, which is supplemented with the testimonies of other persons, documentation sources, transcriptions or archives related to the life or lives in question. This life history has the function of understanding the patterns of social relations, constructions, and interactions which life is immersed in.

In accordance with all these definitions, this study aimed to explore Abdulla's story in an exhaustive, triangulated and methodologically rigorous manner.

Once the account has been drafted, the aim of the life history is not only to recount, but also to use grounded theory to analyse the real-life experience under study. In order to do this, special attention should be given to the different elements which come together to make up the case under study: relationship between the persons involved, reasons why they act, context of the actions and interactions. For example, a diary can help when producing a 'life history', although the diary itself may not be considered a life history since it is limited to describing a series of events without necessarily explaining the process through which they were generated. Life history involves reflection on lived experiences.

The case discussed here can be considered to be a life history because both the drafting of the biography and the development of the study have been carried out by scrupulously following a research procedure (Caetano, 2015). As can be seen in the figure below, the biographical reconstruction used different information sources and various data collection techniques. As a result, an amalgam of vast, plural information related to the focus of the research was obtained and used to carry out multiple triangulations and for saturation purposes. In short, different actions were articulated in order to guarantee methodological rigour without losing any important detail. Likewise, all information was treated and analysed exhaustively using rigorous procedures. 
TABLE 2

Methodological rigour. Scientific character of the work

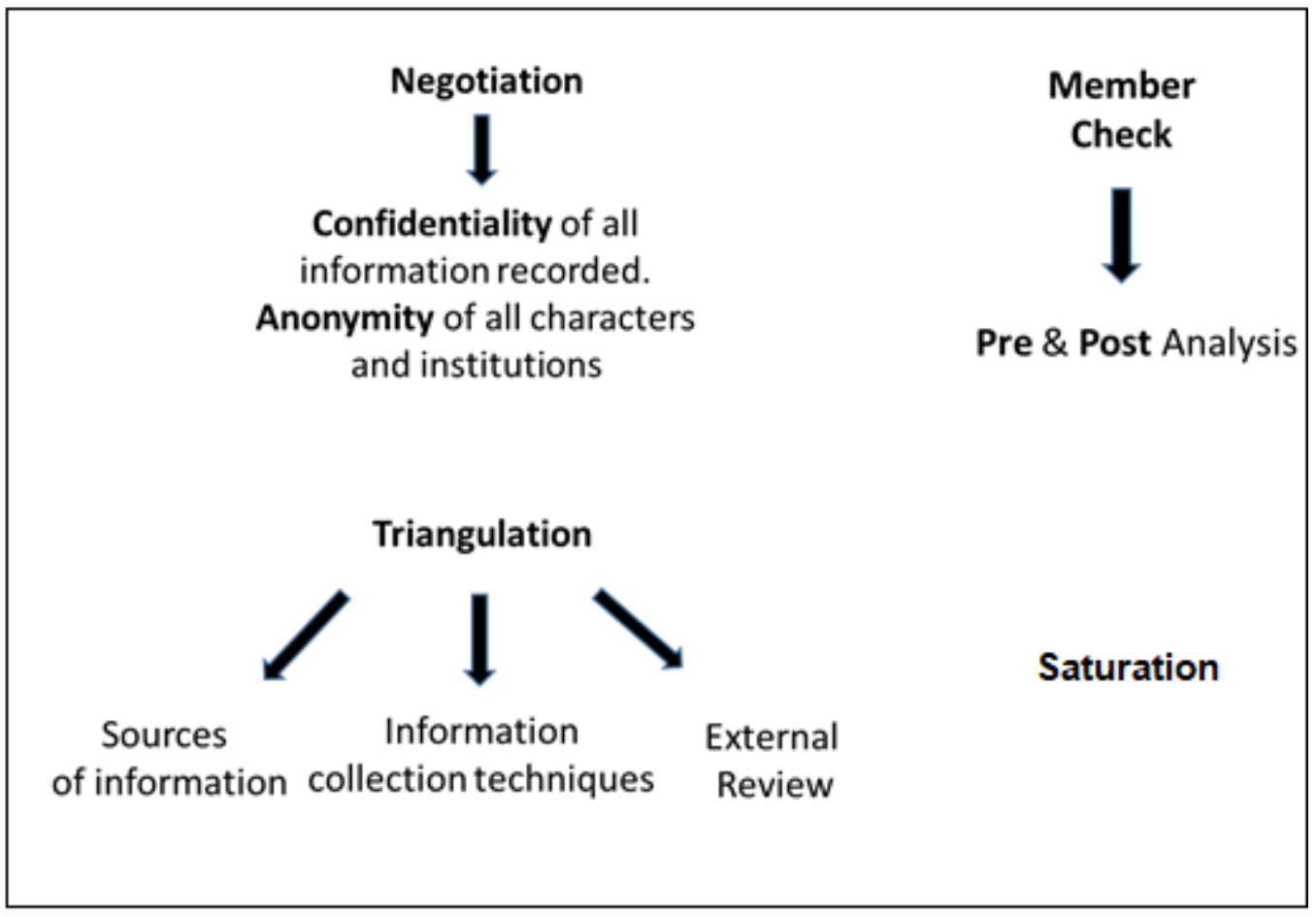

Perhaps the best definition of life history is that of Bertaux (2005), who understands it as a sociological reading of a biography. The biography under study was examined in this way, by focusing on the sociopedagogical perspective that led to reasoned interpretations.

\subsection{Main characteristics of the biographical method}

The biographical approach carries with it idiosyncratic elements, which differentiates it from other qualitative methods and make the biographical approach suitable for the study of certain issues, in particular in relation to minorities, disadvantaged groups and illustrative case studies. Some of these features will be explored below.

\subsubsection{The vision of the 'other'}

Being aware of the 'other's' view of reality is important; particularly of the worldviews of people who belong to minorities, which are generally unknown or perceived through stereotypes. he biographical approach supports the importance of subjectivity in research aimed at analysing social processes (Kraatila, 2019). he concept of 'truth' is placed between quotation marks and is no longer understood as something independent and outside the person, but rather mediated through them (Aguirre-García, 2020). According to Bruner (1991), the most important challenge is not to check the truth in everything recounted, but rather to deal with this interpretation of reality and see how it fits within the lived experience and the significance in that particular life (Michael et al, 2018). It is not 'truth' that is sought, but 'justification' for those interpretations.

In addition, 'the map is not the territory', in other words, the aim is not to graphically recap the 'complete' life of an individual, as this would be a practically impossible task. Not even by filming the life of an individual from the moment of birth all the way through to death could one be certain that 
the most significant data of the life of this person had been recorded, since the subject's interpretations of the different experiences could be missing. For this reason, Abdulla's biography was drafted, to a large degree, by cross-referencing all the statements gathered. It was constructed in an inter-subjective manner, threading together a meta-history with meaning based on the different collected perspectives, which led to a rigorous reconstruction of the history and (socio-structural) context. he member-check carried out with the informants not only guaranteed that the text adhered to the data collected, but also that the constructed narrative was meaningful and exhaustive.

\subsubsection{The process of life: 'A whole life working to have nothing'}

Abdulla's rehabilitation process was a bifurcation (Bessin, Grossetti and Bidart, 2019; Muñiz, 2018), an experience that made the transformation of his life possible. This was at times an experience, a decision or a compendium of decisions that cannot be properly understood without considering the life process in which it was inscribed. The life course is complex and interdependent (Bernardi, Huinink and Settersten, 2019) and therefore a similar approach is needed in order to understand it effectively. It was necessary to be aware of the previous and subsequent stages in order to understand Abdulla's trajectory in a holistic manner and correctly interpret the overall effect of his experience in the youth justice system. This would in turn cast light on the consequences of this experience on his evolution process. It was essential to fully consider Abdulla's background, from his childhood and early adolescence in Morocco, through to the life he built after his detention and probation period in Spain. A bio-gram was developed which included all of the data collected and was used to divide his life into three parts: Before his arrest, The youth rehabilitation process and Postjudicial stage (the following figure shows this more graphically). A bio-gram is a graphical, chronological structure of the events which have given structure to the life of a person. It is a tool that provides a visual representation of power which is objective, simplified and relevant.

FIGURE 1

The bio-gram

$\sum$ Before his arrest $\left.\left.>\begin{array}{c}\text { The youth } \\ \text { rehabilitation process }\end{array}\right\rangle \begin{array}{c}\text { Post-judicial } \\ \text { stage }\end{array}\right\rangle$

It would have been more difficult to comprehend the importance of the rehabilitation process throughout his life had it not been for the panoramic overview of his whole life trajectory, paying attention to the significant events along the way (Söderström, 2019).

In Abdulla's case, the reasons behind these illegal actions cannot be understood without considering the context: the actual life standards in his own country; the frustration of a life without expectations other than living and working in poor conditions; a trajectory of various precarious jobs with long working hours and poor pay during his adolescence; the daily exposure to European living standards promoted by mass media; the geographical proximity between Morocco and Spain (and Europe); the common everyday situations involving drugs, illegal traffic and migration in certain parts of the country as a way of living; and Abdulla's dreams of improving his life conditions. An example of the embedded events, facts and experiences that structured his life trajectory is provided below:

It came about really when I saw how hard it was to do things properly... Doing things the right way is tough, and then you see how people involved in other activities have a lot more, and an easier life. I saw how some people, still very young, had a great life, no problems, everything they could want, while others who had spent their whole lives working had nothing (...). 
People were proud to be involved in illegal activities... It showed they were stronger, cooler, you know. Therefore, if they give you the chance, you are not going to say no. You say that and people don't believe you, because some people actually pay to get involved (...).

One day the gang chief talked to me about coming here [to Spain], here there is a lot of work for me, and so on. I told him I would come.

- [Gang Chief:] There is a boat....

- [Abdulla:] You know what, I'm not going to be getting in and out of a boat; if I do any work it will be over there.

- [Gang Chief:] You don't know what you're saying...

- [Abdulla:] Look, I don't know anything about your life, I'm just telling you what I

want to do, either with you or without you (Abdulla, Biography)

His was really a story of migration with a breaking point and explains why that process of rehabilitation was a watershed that contributed to that transformation in Abdulla's life.

\subsubsection{Embodying the individual and the context: 'I got paid one euro a day'}

Each human being embodies areas of mediation between the individual and the social. A biography not only allows us to see the subject/person, but also the contexts in which they find themselves. This includes both an historical and sociological perspective (Schoofs \& Van De Mieroop, 2019) as the subject of study is inserted into specific space-temporal coordinates corresponding to a precise moment of history (Abbott, 2001). Heidegger (1962) believed that human beings embody time. Each historical moment is a framework, which translates into a social reality with economic, political, cultural and social characteristics. This context shapes the life scenario, which significantly influences the subject's biography.

By virtue of this, a social system can be viewed and studied through the life of an individual. For example, Abdulla's personal experiences become an open door for exploring specific social, cultural, political, economic, and justice systems. Ferrarotti (1993) defined life histories as a complex synthesis of social elements where the universality of society can be appreciated through the singular, namely the subject. In this sense, the theoretical propositions developed as a product of biographical research can be transferred (generalised) to any other case that has substantive similarities with the history and scenarios in which it takes place (Goodson, 2012).

The life of a person is unique and the social environment in which their life occurs requires an interpretative and ecological framework, which is adapted to all its complexity and idiosyncrasy. Waller and Simmons (2009) argue that biographical research requires a quality which they compare to the ability of certain birds to maintain a panoramic view of the overall scenario while at the same time focusing their sights specifically on a small point of interest. Abdulla's biography was a lens that served to merge both perspectives.

The following fragments exemplify some of the major circumstances that shaped Abdulla's life evolution and him as an individual:

- In Morocco:

They do not have any running water, although they have got electricity (...). I suppose they went to the well for water, but his parents paid somebody to bring water to their house, and people, well, you know... His mother, despite her age, had to wash clothes by hand... They had very basic resources (...). The village was severely lacking in infrastructure (Laura: Domestic service worker at the Detention Centre and later Abdulla's foster mother, Biography).

Normal wages in Morocco are two hundred euros [per month], which is what a normal family has to live on. In order to get by, a worker has to earn 6.86 euros a day. That is the law. (...). As for me, I lived in my parents' house, I didn't pay any rent... and I could never count on the 200 euros for myself to see out the month, since a packet of cigarettes in Morocco costs 3.20 euros, here [in Spain] it costs 3.10 euros. For example, you could spend 2 euros on breakfast. Morning coffee costs 80 or 70 [cents], or maybe 
1 euro to sit down in a coffee shop, the same as here (Spain). A waiter earns around 150-180 euros per month. Here a waiter can afford a good car, whilst in Morocco a waiter doesn't even have enough to get by (Abdulla's brother, Biography).

10 dirhams are one euro, I got paid one euro a day. I would leave at eight o'clock in the morning and finish at eight or nine o'clock in the evening (Abdulla, Biography). That was when he was around 14 years old and worked in a café.

- Working for the gang in Spain (he was 17 years old):

I spent money on cars and motorbikes, and on hiring water scooters, in other words, everything that previously I would have thought twice about, now I bought without thinking. I had a car, I had a motorbike; I had everything (Abdulla, Biography).

[The gang] organised private parties with lots of girls, cocaine, hashish and non-stop alcohol, everything, huge tables full of everything, and many times I stayed with them until dawn (Abdulla, Biography).

In this case, the question is not how people 'fit into' systems, but how systems fit into people's lives (Kushner, 2017).

\subsection{Added value of biographical research methodology}

'The march of history has more anonymous processes and experiences than heroes and heroic battles' (Marinas and Santamarina, 1993, p. 10). This approach was particularly suitable for the analysis of the unique, uncertain situations experienced by young offenders. In addition, it casts lights on the oppression that they suffered. This is a social process that informs on the wider social factors at the same time as providing knowledge about the individual. Ferrarotti (1993), who was interested in understanding different forms of exploitation in the last century, was particularly vocal on the benefits of such an approach. The biographical research identified marginal problems and realities in Abdulla's case, rather than, as is often the case, them being forgotten about, unattended or inappropriately dealt with.

Critical theory (Freire, 2015) seeks to transform the circumstances that cause the problems, and the biographical method can partially contribute to this transformation. Disseminating information about these situations can have a consciousness-raising effect and enable society as a whole to learn about circumstances that concern us, but which are too easily ignored. They need to be recounted and remembered. Biographical narration has the power to 'build bridges between different worlds; force us to confront worlds beyond our own; help us see ourselves and those close to us in the stories of others; fight injustice; and initiate a process of change in ourselves' (Witherell, 1998, p. 83). It is essential to better comprehend the marginalised, excluded, discriminated, overlooked or just ignored, those who Edward Said (1979) identifies as 'Others', in order to understand and to re-assess our responsibility as researchers and citizens for the sake of a healthier, more democratic society.

I don't consider the kids in the detention centre criminals. The violence they bring is cultural resistance and there are positive things that are counterhegemonic. Yes, they have committed a crime and that is violent, but that is a language, and the system is more violent with them, because when you grow up in a poor town without expectations, that's violent (...). I always say: 'Maybe I would have done the same as this boy' (Abdulla's tutor at the detention centre, Biography).

Biographical knowledge, recognising the Other's life circumstances, could help us break stereotypes and simplistic views and re-define our common aspirations and thoughts for a more just and equal world (Khurshid, 2017); moreover, it can drive us into much needed actions for change.

In normal circumstances, the case of an immigrant and young offender would have little importance or repercussion. Biographical research is a way of generating counter-narratives and providing a platform to argue for social justice. The biographical method is not used solely to educate on individual or special cases, but to raise awareness and promote an ethical sense, which encourages greater participation in and political commitment to social justice issues. 
These narratives also have the potential to educate and transform the subject of the case study. Abdulla's testimony re-located him in a space of deliberation about what poverty, immigration and vulnerability are. Re-constructing his life path helped him to reflect on it and develop a framework of understanding to enhance meaning in his life.

This job [as a social educator] attracted me for many reasons. For me, it is like I am cleaning something I unwittingly dirtied. Although I cannot go back and change what I did, I realise I helped contaminate people, especially youngsters. So to me this work is in exchange for something I cannot change. I also like my work to be important and have important results, such as helping others, not just being in it for myself. In short, it is impossible to write down everything I think and feel (Abdulla, Biography).

\section{Conclusion}

We live in uncertain and dangerous times for diverse, plural, and democratic societies, and Abdulla's life history exemplifies both the dangers and the ways of meeting challenges. It is an analysis of social change reflected in a single life. Abdulla's biography, as many other stories of minorities, required a panoramic, ethnographic, and holistic view, an integrated subject-context relationship to grasp the multifaceted and complex factors that shaped his life. This historical approach (Feldman-Barrett, 2018) has helped to see, identify and bring to the fore direct and indirect forms of inequality, oppression and hope, as they unfolded in Abdulla's biography. It was also useful to explore complexities in the status quo and remedy substantial gaps and weaknesses in social systems and institutions. We hope this paper can show how biographical research can be an additional way of giving voice to a form of critical social research based on fairness and engagement, and can contribute to social improvement.

\section{ReFERENCES}

Abbott, A. (2001). Time matters. On theory and method. Chicago: University of Chicago Press.

Aguirre-García, J. C. (2020). La posibilidad de la objetividad en ciencias humanas. Cinta de Moebio, 67(1), 1-13. DOI: https://10.4067/S0717-554X2020000100001

Berger, P. and Luckmann, T. (1991). The social construction of reality: a treatise in the sociology of knowledge (No. 10). London: Penguin.

Bernardi, L., Huinink, J. and Settersten, R. (2019). The life course cube: A tool for studying lives. Advances in Life Course Research, 41, 1-13, DOI: https://doi.org/10.1016/j.alcr.2018.11.004

Bertaux, D. (2005). Los relatos de vida. Perspectiva etnosociológica [Life stories. Ethno-sociological perspective]. Barcelona: Bellaterra Editions.

Bessin, M, Bidart, C. and Grossetti, M. (2019). Las bifurcaciones: un estado del arte en la sociología [Bifurcations: A state of the art in Sociology]. CUHSO. Cultura-Hombre-Sociedad, 29(1), 438-451. DOI https://10.7770/071 9-2789.2019.CUHSO.02.A08

Bolívar, A., Domingo, J. and Fernández, M. (2001). La investigación biográfico-narrativa en educación. Enfoque y metodologia [The biographical-narrative research in education. Approach and methodology]. Madrid: La Muralla.

Bruner, J. (1991). Actos de Significado [Acts of Significance]. Madrid: Alianza.

Caetano, A. (2015). Personal reflexivity and biography: methodological challenges and strategies. International Journal of Social Research Methodology, 18(2), 227-242. DOI: https://10.1080/13645579.2014.885154

Denzin, N. (2012). Assumptions of the method. In: J. Goodwin. Biographical research Volume one: Biographical research: starting points, debates and approaches (pp. 63-76). California: SAGE.

Feldman-Barrett, C. (2018). Back to the future: mapping a historic turn in youth studies. Journal of Youth Studies, 21(6), 733-746. DOI: https://10.1080/13676261.2017.1420150 
Ferrarotti, F. (1993). Las biografías como instrumento analítico e interpretative ['Biographies as analytical and interpretative instrument']. In J. M. Marinas and C. Santamarina. La historia oral: Métodos y experiencias [Oral History: Methods and Experiences] (pp. 129-148). Madrid: Debate editorial.

Freire, P. (2015). Pedagogia del oprimido [Pedagogy of the Oppressed]. Madrid: Twenty-first Century Spanish publishers.

Glaser, B. (1965). The constant comparative method of qualitative analysis. Social Problems, 12(4), 436-445.

Goodson, I. (2012). Developing Narrative Theory: life histories and personal representation. UK: Routledge.

Heidegger, M. (1962). Being and time. New York: Harper and Row.

Herron, M. (2019). Ethnographic Methods, Young People, and a High School: A Recipe for Ethical Precarity. Anthropology \& Education Quarterly, 50, 84-96. DOI: https://doi.org/10.1111/aeq.12278

Khurshid, A. (2017). Does Education Empower Women? The Regulated Empowerment of Parhi Likhi Women in Pakistan. Anthropology \& Education Quarterly, 48, 252-268. DOI: https://doi.org/10.1111/aeq.12198

Kraatila, E. (2019). Conspicuous fabrications. Speculative fiction as a tool for confronting the post-truth discourse. Narrative Inquiry, 29(2), 418-433. DOI: https://doi.org/10.1075/ni.19016.kra

Kushner, S. (2017). Evaluative Research Methods: Managing the Complexities of Judgement in the Field. Charlotte, USA: Information Age.

Lewis, O. (1965). Los hijos de Sánchez: autobiografia de una familia mexicana [The sons of Sanchez: autobiography of a Mexican family]. Mexico: Joaquín Mortiz.

Linares, R. F. (2018). Realidad y significación. El giro semiótico como perspectiva y propuesta de ponderación epistémica. Cinta de Moebio, 63(3), 283-296. DOI: https://10.4067/S0717-554X2018000300283

Marinas, J. M. and Santamarina, C. (Eds.) (1993). La historia oral: Métodos y experiencias [Oral History: Methods and Experiences]. Madrid: Editorial Debate.

Michael, K, Solenkom, L., Yakhnich, L., and Karnieli-Miller, O. (2018). Significant life events as a journey of meaning making and change among at-risk youths. Journal of Youth Studies, 21(4), 439-458. DOI: https://10.1080/13 676261.2017 .1385748

Muñiz Terra, L. (2018). El análisis de acontecimientos biográficos y momentos bifurcativos: una propuesta metodológica para analizar relatos de vida [The analysis of biographical events and bifurcative moments: a methodological proposal for analysing life narratives]. Forum: Qualitative Social Research, 19(2), 13, 1-25, DOI: http://dx.doi.org/10.17169/fqs-19.2.2564

Oakley, A. (2010). The social science of biographical life - writing: some methodological and ethical issues. International Journal of Social Research Methodology, 13(5), 425-439. DOI: https://10.1080/1364557100359 3583

Pineau, G. \& Le Grand, J. L. (1996). Life histories. París: PUF.

Pujadas-Muñoz, J. J. (2002). El método biográfico: El uso de las historias de vida en ciencias sociales [The biographical method: How to use life histories in Social Science]. Madrid: Sociological Research Centre.

Roberts, B. (2002). Biographical research. Berkshire: Open University Press.

Rorty, R. (1998). Truth and progress: Philosophical papers (Vol. 3). Cambridge: Cambridge University Press.

Said, E. (1979). Orientalism. New York: Vintage.

Schoofs, K. and Van De Mieroop. D. (2019). Adjusting to new 'truths'. The relation between the spatio-temporal context and identity work in repeated WWII-testimonies. Narrative Inquiry, 29(2), 268-292. DOI: https://d oi.org/10.1075/ni.19020.sch

Smith, L. (2012). Biographical method. In J. Goodwin. Biographical research Volume one: Biographical research: starting points, debates and approaches (pp. 1-36). California: SAGE.

Söderström, J. (2019). Life diagrams: a methodological and analytical tool for accessing life histories. Qualitative Research. https://doi.org/10.1177/1468794118819068

Stake, R. (2010). Investigación con estudio de casos [Case study research]. Madrid: Morata. 
Stanley, L. (2012). On Auto/Biography in Sociology. In J. Goodwin. Biographical research Volume one: Biographical research: starting points, debates and approaches (pp. 101-112). California: SAGE.

Waller, R. and Simmons, J. (2009). Vidas a través de la lente de un ojo de buitre: Interpretando cuentos de aprendices ['Lives through the lens of a vulture's eye: Interpreting apprentice tales']. In J. I. Rivas-Flores and D. HerreraPastor. Vozy educación. La narrativa como enfoque de interpretación de la realidad [Voice and education. Narrative as an approach to the interpretation of reality] (pp. 55-74). Barcelona: Octaedro.

Witherell, C. (1998). Los paisajes narrativos y la imaginación moral. Tomar la narrativa en serio ['Narrative Landscapes and Moral Imagination. Take the narrative seriously']. In H. McEwan and K. Egan. La narrativa en la enseñanza, el aprendizaje y la investigación [Narrative in teaching, learning and research] (pp. 72-85). Buenos Aires (Argentina): Amorrortu Editors. 